\title{
ISLAMIC INTERVENTION PROGRAM MODEL REDUCTION OF BULYYING BEHAVIOR AT SENIOR HIGH SCHOOLS PEKANBARU
}

\section{Zaitun}

Faculty of Tarbiyah and Teacher Training of State Islamic University (UIN) Sultan Syarifkasim Riau, Indonesia

Jl. K. H Ahmad Dahlan No.94, Riau

Email: zaitun.syahbudin@yahoo.com

\begin{abstract}
This study aims to determine the cause of frequent violence in the education and to find behaviour typology leading to bullying that often occur at school and produce appropriate Islamic intervention program model for bullying. This study uses research and development that only focused on hypothetical phase. Writer collects data from several existing Senior High School in Pekanbaru-Riau. Data collection techniques use questionnaire, observation, interview and documentation. To obtain valid data, the researcher also conducted triangulation. The study concluded that intervention model can be done by streamline the peer coaching, religious mentoring intensively periodically that conducted school with involving counselling and religious teachers and maximize co-operation between parents, teachers and schools to make effective group counselling, mediation and use of ICT in the learning process.
\end{abstract}

Keywords: Bullying, Model, Intervention Program

\begin{abstract}
Penelitian ini bertujuan untuk menentukan penyebab seringnya kekerasan yang terjadi dalam dunia pendidikan untuk menemukan tipe perilaku mengarah pada bullying yang sering terjadi di sekolah dan untuk. menghasilkan model program intervensi Islami yang sesuai untuk. mengatasi bullying. Kajian ini merupakan penelitian dan pengembangan yang hanya berfokus pada fase hipotesis saja. Penulis mengumpulkan data dari beberapa SMA yang ada di Pekanbaru Riau. Teknik pengumpulan data menggunakan kuesioner, obersvasi, wawancara, dan dokumentasi untuk mendapatkan data yang valid. Peneliti juga menggunakan data triangulation. Penelitian ini menyimpulkan bahwa model intervensi dapat dilakukan dengen mengefektifkan peer coaching, intensif mentoring agama rutin yang dilakukan sekolah dengan melibatkan bimbingan konseling dan guru agama serta memaksimalkan kerja sama antara orang tua, guru, dan sekolah untuk membuat kelompok konseling yang efektif, mediasi, dan penggunaan ICT dalam proses pembelajaran.
\end{abstract}

Kata Kunci: Kekerasan, Model, Program Intervensi 


\section{INTRODUCTION}

School is educational institutions which should overcome educational program. This institution precisely is like an iceberg on the surface. Lately, there are many students are arrested for various cases including bullying cases. Bullying is power aggressive behaviour of students who performed repeatedly by one/group of students who have power, against other students who are weaker with the aim of hurting the person. Another definition of bullying is the use of power or strength to hurt someone or a group, so that victims feel depressed, traumatized and helpless. Bullying as the use of aggression in any form is aimed at hurting or cornering other people physically and mentally. Bullying can be physical actions, verbal, emotional, and sexual. Bullying is a form of behaviour of coercion or attempted physical and psychological harm to weaker person or group by a person or group of people who feel more powerful.

Bullying is no longer an issue that is underestimated and underrated, even denying its existence. Students who are victims of bullying will spend a lot of energy to think about how to avoid bullies so that they have little energy to learn. Likewise with bullies, they will have difficulty in social relationships and when this behaviour occurs until they are adults, it certainly will cause a negative impact wider.

This fact then, school authorities are such as educators, parents and some authorities at school have a big influence in preventing bullying among students. This is done in order students feel safe and peaceful at school. Educators in the scientific capacity and understanding possessed required providing guidance, protection and early intervention are done proportionally and professional in Indonesia. Bullying is not as severe occurs in others country. It is necessary for appropriate prevention strategies in order bullying problem which does not occur in this country. In line with the implementation of curriculum 2013, it focuses on the approach of attitude/character aspect as well as aspects of knowledge and skills. This strengthened that learning approaches lead to the Akblakul Karimah become a necessity.

Several Senior High School are located at Pekanbaru city allegedly had a tendency to act mil, moderate, and severe bullying as seniority at school, fighting among students, being rude to friends especially in speech and attitude, formed group at school, etc. This causes unrest among students, teachers and parents. In fact, there are many students involved in negative behaviors that lead to acts of bullying. Although there are some actions that occur bullying behavior is not at the level of severe, if it does not overcome seriously can cause several bullying. 
Therefore, teachers and other authorities should be professionally to create appropriate program model in intervention based islamic to help students get comfort at school.

Based on the identification of the problem above, the formulation of the problem in this study are as follows:

1. What factors do cause bullying behaviour among students at senior high school Pekanbaru?

2. What are behaviour typology lead to bullying that often occur among students at senior high school Pekanbaru?

3. What Islamic Intervention Program Model are appropriate with perpetrator bullying behaviour at Senior High Schools Pekanbaru?

The objectives of the research are:

1. To determine the cause of frequent violence in education

2. To determine what typology of behaviour leads to bullying often happen at school.

3. To produce appropriate Islamic Intervention program Model for perpetrator bullying

\section{FINDINGS AND ANALYSIS}

\section{The Concept of Bullying}

An act categorized as bullying if delinquency is already happening continuously and the action is done by a person having more power. The word of bullying is derived from English, it is Bull namely bull butting bull. The term was eventually taken to describe a destructive act. In contrast to other countries such as Norway, Denmark and Finland that called bullying as mobbing. In Indonesian, the word of Bullying means browbeaten bully, those who disturb the weak. These words of course are unfamiliar with us, but it has happened in our environment.

There are some definitions of bullying defined by Dan Olweus, a pioneer of bullying prevention revealed that bullying is when someone repeatedly and on purpose says or does mean or hurtful things to another person who has a hard time defending himself or herself. Bullying is an act committed by a person repeatedly and deliberately to others. Ardynovan in his book reveals that bullying is a negative behavior that causes a person in situation of discomfort or hurt and usually occurs repeatedly.

Furthermore, according to Olweus as quoted Kathryn Geldard (2012, p. 171) suggests that bullying can be defined as an act or aggressive behaviour that is intentional, committed by a group of people or a person repeatedly from time to time on a victim who cannot defend themselves easily. 
Coloroso (2007, p. 44) in his book defines bullying as an oppression. He argues that bullying will always involve the following four elements:

1. Power imbalance. Bullying not a competition between siblings, nor fights involving two similar parties. Perpetrators of bullying may be people who are older, bigger, stronger, more adept verbally, higher social status, or originate from different races;

2. Desire to burt. In bullying, there is no an accident or mistakes, there is no chance in the ostracism of the victim. Bullying means to cause emotional pain or physical injury, involving actions that can hurt, and the cause of pleasure in the heart of the actor while watching the suffering of the victims;

3. The threat of further aggression. Bullying is not intended as an event that only happens once, but also repetitive or likely to be repeated;

4. Terror. It happens when bullying is increasing. Bullying is systematic violence used to intimidate and maintain dominance. Terror is not just a way to achieve of bullying but also as the goal of bullying.

From the opinions above, it can be concluded that bullying is negative behaviors carried out by someone who has a stronger power to others who are weaker and the behavior occurs repeatedly.

\section{Typology of Bullying}

Bullying can be shaped directly or indirectly. Directly is such as physical assault and verbal. Whereas indirect forms such as spreading slander or damaging other people's belongings. The most recent types of bullying today is cyber bullying, which is bullying use a mobile phone or via the internet.

Olweus (2014, p. 172) argues that acts of bullying are: 1) Verbal bullying such as calling names and verbal harassment, 2) Leaving another person out of a group, 3) Physical bullying such as pushing, hitting, kicking or 4) Telling lies and spreading false rumours. 5) Taking away money or other things or damaging personal property. 6) Threatening or forcing another person to do things they do not want to do 7) Racial bullying 8) Sexual bullying 9) Cyber-bullying (via cell phone or the Internet).

According to Olweus's (2014, p. 173) argument above the acts of bullying are among others, 1) bullying in words such as calling name with the purpose of harassment. 2) pull out a person from a group. 3) Bullying in physical such as pushing, hitting, or kicking 4) Telling Lies and spreading false rumors. 5) Eliminate money or damage other things belonging to a person. 6) Threaten or coerce others to do things they do not want to do. 7) Bully a particular race. 8) Sexual bullying. 9) Cyber-bullying (via mobile phone or internet). 
Furthermore Coloroso (2007, p. 47) suggests that there are three forms of bullying namely verbal, physical and relational. Each of these forms can cause adverse effects respectively. Sometimes these are often combined to create a more powerful attack. Verbal bullying is the most common form of repression carried out by boys and girls. The words are powerful tools and can break children spirit of the child who receives it. Verbal bullying can call nickname, reproach, slander, criticism, insults and statements nuanced sexual advances or sexual harassment.

While physically Bullying can be done by beating, choking, elbowing, punching, kicking, biting, headlock, clawing and spitting on the child who is being bullied. Besides perpetrator bend the limbs of children who are victims, damaging and destroying clothes and thing of grinded children. Then, relational bullying is to be the most difficult to detect. Relational oppression is weakening dignity of victims systematically through neglect, isolation, exclusion, or avoidance. These bullying can be used to isolate or reject a friend in the association. This behaviour can include such hidden attitudes such aggressive outlook, gaze, sigh, shoulders shuddering, scorn, and mocking laughter.

From some opinions above it can be concluded the action of bullying included:

1. Bullying verbally

2. Bullying physically

3. Bullying in relationally

4. Telling lies and spreading false rumours

5. Eliminate money or other and damage

6. Threatening or forcing others to do things they do not want to do

7. Bullying particular race

8. Bullying Sexually

9. Cyber-bullying (via mobile phone or internet).

\section{Intervention Program at Schools}

The school environment has a major role in developing adolescent life. The function of school is carrying out formal teaching, and serves as a point of reference and protection if a student is having problems. Therefore, the school appointed a tutor to handle and guide students in dealing with problems they experienced through guidance and counselling services.

Furthermore Amirah (2012, p. 149) suggested that counselling process that empathy can be realized strategies to handle bullying victim that may be impaired, either physical or psychological. Skills empathize to bullying victim needed in order clients want to tell the traumatic events which they experienced. The position of counsellor as people who understand and can 
be advocates for themselves bullying victims, will be perceived as a motivator for him. It is expected the client is able to defend themselves against bullying behaviour in the future. Besides, the teachers also have participation in the handling of bullying behaviour.

There are several diverse approaches that can be implemented, such as crisis approaches, remedial approach, a preventive approach and the approach to development. Preventive approach is an approach to anticipate on individual problem does not happen. Teachers provide some information and skills to prevent certain problems. Preventive approach is not always based on a particular theory of special, but adapted to the needs. To overcome bullying problem, it is needed comprehensive policies at school. A policy involves component from teacher to student, from the principal to the parents, the cooperation between teachers, parents and related community or other parties such as the police, law enforcement and so on which are indispensable in addressing this issue.

Furthermore Ehan (2005, p. 48) revealed that the role of parents at home is also important. Parents should be able to create good communication with the children and provide children with religious understanding and instilling Ablakul Karimah which is always carried out at home environment, it causes children who will always imitate parents behaviour. Giving the example of the children would be better than giving advice.

The way that can be done by the school is to create an anti-bullying program at schools. According to Huneck as quoted Ehan (2005, p. 56) who is also an expert in bullying interventions that work at the Jakarta International School, bullying will occur continually at schools, when adults are not aware about bullying behaviour. Unconstructed mutual relationships with students, are not aware the caused by bullying, do not realize the impact of bullying damage student learning activities, and there is no effective intervention from school. The usefulness of anti-bullying programs at school are (1) Instil of congeniality that feel peaceful is a right and belongs to everyone (2) Supply students to make decisions.

The appropriate idea to solve bullying phenomena at schools is a peaceful school program. Peaceful school is a school of peace. A school that has conducive in teaching learning process, guarantees comfort and security on every component at school because of affection, care, trust and togetherness.

Compilation of peaceful school program should include the following aspects:

1. Mutual trust: If any component at school has a trust towards each other, the student will not feel pressured at school. When the school made 
certain regulations, students will believe that the schools have good will in order to realize the smooth process of learning.

2. Cooperation: Cooperation can reduce the tendency of individuals to be individualistic and selfish with their own selfish. School of peace and non-violence requires the cooperation among school component.

3. Tolerance: It needs to be instilled at students in schools in an effort to create a cultural peace against violence in schools. Tolerance can be increased through by improving individual empathy.

4. Acceptance of Difference: Acceptance of difference is to accept that other people also have opinions, ideals, religious background, race, and ethnicity that may be different. Therefore there is no reason to act in a discriminatory manner.

5. Respect for the Environment. School peace can be created when sustainability and environmental soundness school can be properly maintained. Environmental sustainability can be created when school component has ecologically.

\section{Islam Religion of Rahmatan Lil'alamin as Model}

Islamic in terminology, is the religion brought by the Prophet and Messenger on each of his day ended with the prophet of Muhammad SAW, QS. Al-Baqarah 131, 136, and 208. According to al-Jurjani, the meaning of Islam is submission and obedience to what is conveyed by the Prophet Muhammad. While in interpretation of Al-Kasysyaf mentioned that Islam is any recognition that professed verbally. Although unsupported by whole heartedly, these pledges including Islam. If the pledge is supported by whole heartedly, so the pledge is faith. Islam is the most complete, religion which is directed to the benefit of mankind through Muhammad. The gate was opened to the safety and happiness of mankind in the world so that human society leave periods immaturity and incapacity of their thinking, preparing to achieve human humanity as a whole, and raise awareness to accept the teachings of the noble spiritual and implement in practice.

There are several principles of Islam relevant including:

First, the source of normative Islam is al-Qur'an and Hadith. As the instructions of Al-quran contains a thorough about human life. They are faith, Syariah, stories of the previous race, promises and threats, the principles of science, and so forth, while the hadith of the Prophet gives detailed explanations on the meaning of $\mathrm{Al}$-quran

Second, the basic teaching of Islam covers belief, Syariah and Islamic morality. Teaching of akblak concerned with her mental symptoms lead to behaviour. When the behaviour is good, it is called good $\mathrm{deed} /$ commendable. Conversely if the behaviour that arises is bad, it is called 
bad character/despicable. In morals, good and bad refers to Islam provision which refers to the provisions of Allah SWT. Many studies have shown that good Akblakal-Mahmudah is very conducive to peace of mind, solidarity, harmony and peace, while negative emotions is a potential for the emergence of snuggery attitude, hostility and other forms of violence.

Third, the source and Islam teachings should be actualized in life. Actualization is concerning the implementation of the rights and obligations of a person to God, His Messenger, himself, our fellow human beings, society, the universe, etc. The actualization embodied in knowledge, attitude, behaviour and lifestyles that are filled with consciousness of Taubid to God as evidenced by good works, obedience and devotion to Allah. Actualization also occurs within oneself in the form of maintaining good name, dignity, maintaining sexual honour and things damaging and forbidden. As for the self-actualization of fellow human beings manifested in social solidarity, tolerance, democracy, mutual respect, help, mutual aid and so forth.

Based on the explanation above, abstracted that learning method presented by Al-Qur'an and Hadith. First is amaliyah method or practice. The teachings of Islam are not sufficiently provided with advice, but require real charity in order Islam is not understood merely symbols, but formed in the totality of human being. Second is Amal ma'ruf nabi munkar method. The implication or Amal ma'ruf nabi munkar methods in education can manifest through the enforcement of rules, discipline, code of ethics, discipline if there are solved and resolved peacefully, mutual understanding and respect for fellow human beings. Third is Advice method. Indeed al-Qur'an comes with the advice and clear lesson for humans. Teachers in schools can explain to students the verse about the ban to mock the shortcomings of others. The word Allah in QS. Al-Hujurat,[11]:

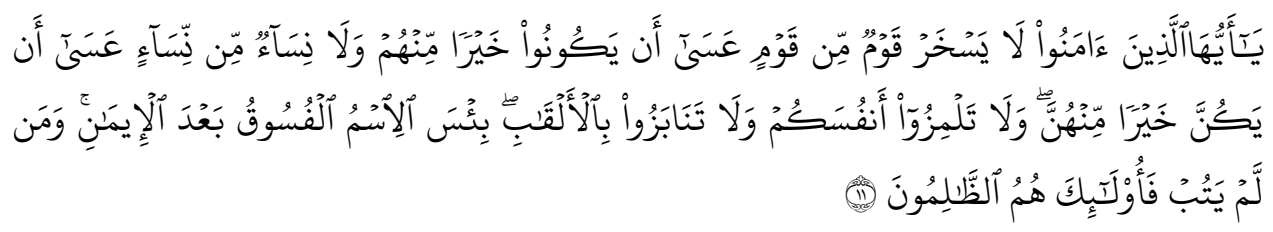

O you who have believed, let not a people ridicule [another] people; perbaps they may be better than them; nor let women ridicule [other] women; perbaps they may be better than them. And do not insult one another and do not call each other by [offensive] nicknames. Wretched is the name of disobedience after [one's] faith. And whoever does not repent - then it is those who are the wrongdoers.

Teachers can provide bullying relate to the religious bullying. More students are expected to refrain from acts that lead to bullying. In addition, 
Rina Mulyani (3013, p. 17) in his writing suggests that spiritual counseling approach can also solve the occurrence of bullying in schools. Spiritual counselling is a process of providing assistance to individuals in order to have the ability to develop its nature as religious beings. In spiritual counseling there is the intervention of God in human life to help him to cope with the problem and make change for the better.

This study used research and development only focused on hypothetical phase. According to Borg and Gall (1989, p. 772), research development is "processes used develop and validate educational product" or also called "research based development", which aims to improve the quality of education. Added again by Borg and Gall, a series of steps that must be taken in the R \& D approach, namely:

1. Research and information collecting, this stage is preliminary study. The activities are literature studies underlying the model of Islamic intervention program to be developed, then design a research framework.

2. Planning, after a preliminary study, the next step of designing a variety of activities and procedures that will be pursued in research development in the field of research including data collection

3. Develop preliminary of product, activities are directed to design first draft of Islamic intervention program model to reduce bullying behaviour.

4. Preliminary field testing and product revision. The purpose of this stage is to obtain a description of a due diligence model to be developed. Preliminary trial results are limited and do repeatedly in order to obtain a draft model prepared test.

5. Main field testing and product revision, this stage is called the main trial with a broader scope. This activity is performed to determine whether a model that will be developed completely as had been expected. This phase uses experiment design. The main trial results used to revise the model to obtain a model that is ready to be validated.

6. Operational field tests and final product revision. The purpose of this stage is to determine a model that was developed completely ready to be implemented in schools without involving researchers or developers model. This stage is called the model validation test.

7. Dissemination and implementation. This stage is reached in order for the newly developed models can be used by the school. The core activity of this phase is to disseminate the results development product.

This research was performed in Pekanbaru. The city election is based on the consideration that Pekanbaru is the capital of Riau province that is growing, as the capital of the province, would has a complexity problems 
require serious treatment. The location used as a place of research was SMAN 12 representing Tampan districts; SMAN 8 representing Sail district; SMAN 5 representing Marpoyan Damai district; SMAN 2 representing Payung Sekaki and SMAN 7 representing Rumbai district.

The subjects of this research were 18 religious teachers and counselling teachers and 97 students of SMAN Pekanbaru is indicated to bullying. The research object was Islamic intervention program model in reducing bullying behaviour for students.

Writer collects data from several existing SMAN in Pekanbaru-Riau. By using various techniques, they are:

1. Questionnaire

The questionnaire was for at students to obtain data on the forms of bullying behaviour often made by perpetrators of bullying and the factors that influence bullying occurs among students.

2. Observation

Writer did direct observation based on observation guide. To maintain the validity of this method, the writer used field notes. Observation is intended to observe trends typology of bullying behaviour done by students at school.

3. Interview

The interview is the process of asking questions to the informant both primary and secondary informant refers to the instrument interviews to obtain information about what the Islamic intervention program models are in reducing bullying behaviours among students addressed to religious teachers and counselling teacher.

4. Documentation is a collection of research data, mainly carried out by collecting documents related to the students' behaviour. It is taken from document of counsellor teacher at school, school brochures, leaflets, etc.

To obtain valid data, the researcher also conducted triangulation. Triangulations of research include:

1. Triangulation with sources is done by comparing and reviewing the data and observations and interviews

2. Triangulation method is done by comparing the data and reviewing information of observations and interviews

3. Triangulation with theory is done by comparing data from observations and interviews with related theories

Qualitative data processing is done by using the following steps: first, the data collection is collecting data through observation and in-depth interviews and documentation. Therefore, writer used field notes and interview guides that have been prepared. Second, data reduction is recorded 
or typed again in the form of a description or detailed report. Field reports are reduced, summarized, selected, given a more systematic arrangement to make easy controlled. Third, data display is an attempt to look at the overall or certain parts of the research data. For it was made in a variety of matrices, graphs and charts. Fourth, data verification attempts to find meaning of the data collected through data interpretation. Data processing is performed by inventory and data classify the data that has been collected to make an objective and systematic description.

The data analysis was also done logically and critically through qualitative descriptive of Analytical Philosophy approach, a research method that is intended to describe the phenomena, which takes place at this time or past time. As for the quantitative data, researcher used analysis quantitative descriptive percentage.

In conclusion manufacture data analysis process is continued with the search for the relationship between what is done, how to do, why do something like that and how is the effect. Therefore, writer found patterns, themes, categories, models, equations and so on. This research is done in stages, starting from the provisional conclusions, but with increasing data, then re-verification.

\section{Research Discussion}

\section{Factors Influencing the Emergence of Bully Behaviour among Students}

Table 1

Recapitulation of Students Questionnaire Factors Influences Bullying Behaviour among Students at Sman Pekanbaru

\begin{tabular}{|c|c|c|c|c|c|c|c|c|c|}
\hline \multirow[b]{2}{*}{ No } & \multirow[b]{2}{*}{ Statements } & \multicolumn{2}{|c|}{ always } & \multicolumn{2}{|c|}{ often } & \multicolumn{2}{|c|}{ seldom } & \multicolumn{2}{|c|}{ never } \\
\hline & & $\mathbf{F}$ & $\begin{array}{c}P \\
(\%)\end{array}$ & $\mathbf{F}$ & $\begin{array}{c}\mathbf{P} \\
(\%)\end{array}$ & $\mathbf{F}$ & $\begin{array}{c}P \\
(\%)\end{array}$ & $\mathbf{F}$ & $\begin{array}{c}\mathbf{P} \\
(\%)\end{array}$ \\
\hline 1 & Have low self-esteem & 11 & $11 \%$ & 9 & $9 \%$ & 12 & $12 \%$ & 64 & $66 \%$ \\
\hline 2 & $\begin{array}{l}\text { Understanding of the } \\
\text { moral/akhlak low }\end{array}$ & 11 & $11 \%$ & 4 & $4 \%$ & 32 & $33 \%$ & 50 & $52 \%$ \\
\hline 3 & $\begin{array}{l}\text { Glad to perform acts that } \\
\text { violate the norms }\end{array}$ & 10 & $10 \%$ & 14 & $14 \%$ & 33 & $34 \%$ & 38 & $39 \%$ \\
\hline 4 & Desiring awarded a friend & 22 & $23 \%$ & 30 & $31 \%$ & 25 & $26 \%$ & 22 & $23 \%$ \\
\hline 5 & $\begin{array}{l}\text { Not knowing where the good } \\
\text { and bad }\end{array}$ & 9 & $9 \%$ & 22 & $23 \%$ & 20 & $21 \%$ & 31 & $32 \%$ \\
\hline 6 & Too confident & 10 & $10 \%$ & 29 & $30 \%$ & 29 & $30 \%$ & 18 & $19 \%$ \\
\hline 7 & $\begin{array}{l}\text { Parents who are too spoil the } \\
\text { child }\end{array}$ & 22 & $23 \%$ & 13 & $13 \%$ & 40 & $41 \%$ & 22 & $23 \%$ \\
\hline 8 & Not getting affection & 10 & $10 \%$ & 16 & $16 \%$ & 13 & $13 \%$ & 56 & $58 \%$ \\
\hline 9 & Don't feel cared for & 15 & $15 \%$ & 7 & $7 \%$ & 17 & $18 \%$ & 56 & $58 \%$ \\
\hline 10 & Families were broken home & 9 & $9 \%$ & 16 & $16 \%$ & 16 & $16 \%$ & 53 & $55 \%$ \\
\hline 11 & $\begin{array}{l}\text { The pattern of parental } \\
\text { education on children is wrong } \\
\text { and wrong }\end{array}$ & 12 & $12 \%$ & 11 & $11 \%$ & 15 & $15 \%$ & 55 & $57 \%$ \\
\hline
\end{tabular}




\begin{tabular}{|c|l|l|l|l|l|l|l|l|l|}
\hline \multirow{2}{*}{ No } & \multicolumn{1}{|c|}{ Statements } & \multicolumn{2}{|c|}{ always } & \multicolumn{2}{|c|}{ often } & \multicolumn{2}{|c|}{ seldom } & \multicolumn{2}{|c|}{ never } \\
\cline { 3 - 10 } & & $\mathbf{F}$ & $\begin{array}{c}\mathbf{P} \\
\mathbf{( \% )}\end{array}$ & $\mathbf{F}$ & $\begin{array}{c}\mathbf{P} \\
\mathbf{( \% )}\end{array}$ & $\mathbf{F}$ & $\begin{array}{c}\mathbf{P} \\
\mathbf{( \% )}\end{array}$ & $\mathbf{F}$ & $\begin{array}{c}\mathbf{P} \\
\mathbf{( \% )}\end{array}$ \\
\hline 12 & Parents tend to be protective & 9 & $9 \%$ & 24 & $25 \%$ & 28 & $29 \%$ & 36 & $37 \%$ \\
\hline 13 & $\begin{array}{l}\text { Parents never appreciate the } \\
\text { willingness of children }\end{array}$ & 12 & $12 \%$ & 15 & $15 \%$ & 23 & $24 \%$ & 47 & $48 \%$ \\
\hline 14 & Parents are too loud and shout & 11 & $11 \%$ & 10 & $10 \%$ & 22 & $23 \%$ & 54 & $56 \%$ \\
\hline 15 & Parents too succumb & 4 & $4 \%$ & 13 & $13 \%$ & 38 & $39 \%$ & 42 & $43 \%$ \\
\hline 16 & $\begin{array}{l}\text { Behavior of parents that cannot } \\
\text { be imitated }\end{array}$ & 7 & $7 \%$ & 11 & $11 \%$ & 26 & $27 \%$ & 53 & $55 \%$ \\
\hline 17 & $\begin{array}{l}\text { Lack of parental supervision to } \\
\text { impressions, games, social } \\
\text { media }\end{array}$ & 9 & $9 \%$ & 21 & $22 \%$ & 24 & $25 \%$ & 43 & $44 \%$ \\
\hline 18 & Having a rough peers & 11 & $11 \%$ & 14 & $14 \%$ & 39 & $40 \%$ & 31 & $32 \%$ \\
\hline 19 & Peer smokers & 13 & $13 \%$ & 17 & $18 \%$ & 24 & $25 \%$ & 36 & $37 \%$ \\
\hline 20 & Peers are grumpy & 13 & $13 \%$ & 22 & $23 \%$ & 41 & $42 \%$ & 21 & $22 \%$ \\
\hline 21 & $\begin{array}{l}\text { Peers often invited to do } \\
\text { violence }\end{array}$ & 15 & $15 \%$ & 13 & $13 \%$ & 21 & $22 \%$ & 44 & $45 \%$ \\
\hline 22 & Having peers who like damage & 8 & $8 \%$ & 17 & $18 \%$ & 23 & $24 \%$ & 49 & $51 \%$ \\
\hline 23 & $\begin{array}{l}\text { Peers like to disturb good } \\
\text { friends in class and outside of } \\
\text { class }\end{array}$ & 5 & $5 \%$ & 20 & $21 \%$ & 35 & $36 \%$ & 37 & $38 \%$ \\
\hline 24 & $\begin{array}{l}\text { There is no strict sanctions on } \\
\text { teachers }\end{array}$ & 13 & $13 \%$ & 12 & $12 \%$ & 33 & $34 \%$ & 39 & $40 \%$ \\
\hline 25 & $\begin{array}{l}\text { Teachers tend to let violence at } \\
\text { school song select sanction } \\
\text { violations of bully behaviour }\end{array}$ & 8 & $8 \%$ & 14 & $14 \%$ & 27 & $28 \%$ & 52 & $54 \%$ \\
\hline 27 & Watching that tends to violence & 14 & $14 \%$ & 11 & $11 \%$ & 30 & $31 \%$ & 44 & $45 \%$ \\
\hline & Using social networks & 22 & $23 \%$ & 25 & $26 \%$ & 22 & $23 \%$ & 37 & $38 \%$ \\
\hline
\end{tabular}

Based on the recapitulation of questionnaire above, it is found that factors influenced bullying behaviour among students who are desire to get appreciation/attention from their peers and parents who are too indulgent. Children who were active in using social networking media to bully behaviour gained $23 \%$. The next factors are the child does not get the attention, and peers who often invite to do violence are $15 \%$. Then the children often watch the show violence action through television, movies and other gained 14\%. Factors having peers smokers, grumpy, no doubt firmly from teacher are 13\%. Parents do not appreciate the willingness of the child gained $12 \%$. Then parents like to shout too loud children so that the children have low self-esteem and lack of moral understanding and character, have a rough peer are at $11 \%$.

From the explanation above it shows that external factors of children are on the right rate from parent education, bad friends and bad film watched by children, wrong impressions, has not been enforced strict sanctions toward the perpetrators of bullying also affect emerging behaviour bully among students. 
Siswati and Costrie Ganes Widayanti. Faculty of Psychology, University of Diponegoro Semarang in 2009 with the title: The phenomenon of bullying in elementary schools in Semarang: A Descriptive Study. Based on the results of Siswati and Costrie Ganes Widayanti, it can be concluded that knowledge and understanding of the school about bullying is still relatively limited, especially regarding typology of bullying. A preventive treatment program in an integrated manner is an effective way undertaken to overcome bullying. Teachers have very important role to get awareness about bullying and develop affirm policy consistent towards this behaviour and to improve the skills and support both the perpetrators and victims of bullying so that it will achieve a safe environment for students.

Nissa Ardilla, from Criminology Department of Indonesia University in 2009 under the title: The Effect of Social Control toward Bullying Behaviour in Junior High School Students. Based on the research results of Nissa Ardilla, it can be concluded that from the results of correlation and regression in this study showed a strong relationship, significant, positive, and influential among social control variable and bullying behaviour variable.

Rina Mulyani, from the Faculty of Da'wa and Communication of Islamic University of Sunan Kalijaga in 2013 with the title: Spiritual Counseling Approach to solve Bullying (Violence) Students at SMAN 1 Depok Sleman, Yogyakarta. Based on the results of research Rina Mulyani, Counselling is handling of the cases of violence by using spiritual counseling approach embodied in several programs such as spiritual guidance classically, recitation classes, individual counseling and responsive service. In addition interventions are used by teachers at schools is the Ecumenical intervention, namely giving services that are not doctrinal and universal to all religions.

There is a difference between the third researches above with the title of writer. Siswati and Costrie Ganes Widayanti from Faculty of Psychology, University of Diponegoro in 2009 examines the phenomenon of bullying in elementary schools in Semarang. While Nissa Ardilla from Criminology Department of Indonesia University in 2009 studied the Influence of Social Control toward Bullying Behaviours in Junior High School Students. Then, Rina Mulyani is from Da'wa and Communication Faculty of Islamic University Sunan Kalijaga in 2013 conducted a research about Spiritual Counselling Approach to solve Bullying (Violence) Students. The similarities are examines the phenomenon of bullying. 
Table 2

Recapitulation Students' Questionnaire Based on Typology of Bullying Behavior

\begin{tabular}{|c|c|c|c|c|c|c|c|c|}
\hline \multirow{2}{*}{ STATEMENT } & \multicolumn{2}{|c|}{ Always } & \multicolumn{2}{|c|}{ Often } & \multicolumn{2}{|c|}{ Seldom } & \multicolumn{2}{|c|}{ Never } \\
\hline & $\mathbf{F}$ & $\mathbf{P}(\%)$ & $\mathbf{F}$ & $\mathbf{P}(\%)$ & $\mathbf{F}$ & $\mathbf{P}(\%)$ & $\mathbf{F}$ & $\mathbf{P}(\%)$ \\
\hline Physical ridicule & 19 & $20 \%$ & 15 & $15 \%$ & 24 & $25 \%$ & 39 & $40 \%$ \\
\hline $\begin{array}{l}\text { Ridicule associated } \\
\text { with the work of } \\
\text { parents }\end{array}$ & 5 & $5 \%$ & 15 & $15 \%$ & 24 & $25 \%$ & 53 & $55 \%$ \\
\hline Physical ridicule & 13 & $13 \%$ & 12 & $12 \%$ & 18 & $19 \%$ & 53 & $55 \%$ \\
\hline Mock & 18 & $19 \%$ & 10 & $10 \%$ & 19 & $20 \%$ & 50 & $52 \%$ \\
\hline $\begin{array}{l}\text { Excluded from the } \\
\text { study group }\end{array}$ & 11 & $11 \%$ & 29 & $30 \%$ & 23 & $24 \%$ & 54 & $56 \%$ \\
\hline Driven & 5 & $5 \%$ & 10 & $10 \%$ & 36 & $37 \%$ & 46 & $47 \%$ \\
\hline Beaten & 4 & $4 \%$ & 10 & $10 \%$ & 36 & $37 \%$ & 46 & $47 \%$ \\
\hline Kicked & 10 & $10 \%$ & 5 & $5 \%$ & 30 & $31 \%$ & 52 & $54 \%$ \\
\hline The gossip & 18 & $19 \%$ & 13 & $13 \%$ & 28 & $29 \%$ & 38 & $39 \%$ \\
\hline Humiliated in public & 11 & $11 \%$ & 10 & $10 \%$ & 31 & $32 \%$ & 44 & $45 \%$ \\
\hline Framed friend & 11 & $11 \%$ & 8 & $8 \%$ & 22 & $23 \%$ & 46 & $47 \%$ \\
\hline Lifted skirt & 3 & $3 \%$ & 8 & $8 \%$ & 20 & $21 \%$ & 66 & $68 \%$ \\
\hline $\begin{array}{l}\text { Ridiculed because of } \\
\text { social races }\end{array}$ & 3 & $3 \%$ & 9 & $9 \%$ & 18 & $19 \%$ & 60 & $62 \%$ \\
\hline Pull strap camisole & 4 & $4 \%$ & 4 & $4 \%$ & 10 & $10 \%$ & 79 & $81 \%$ \\
\hline $\begin{array}{l}\text { Using social networks } \\
\text { (the Internet) for } \\
\text { embarrass }\end{array}$ & 10 & $10 \%$ & 4 & $4 \%$ & 16 & $16 \%$ & 68 & $70 \%$ \\
\hline Open disgrace friend & 8 & $8 \%$ & 9 & $9 \%$ & 23 & $24 \%$ & 57 & $59 \%$ \\
\hline $\begin{array}{l}\text { Spread personal } \\
\text { photos without } \\
\text { permission of the } \\
\text { owner }\end{array}$ & 9 & $9 \%$ & 13 & $13 \%$ & 11 & $11 \%$ & 65 & $67 \%$ \\
\hline There seniority & 13 & $13 \%$ & 10 & $10 \%$ & 23 & $24 \%$ & 51 & $53 \%$ \\
\hline Superior classmates & 6 & $6 \%$ & 12 & $12 \%$ & 24 & $25 \%$ & 55 & $57 \%$ \\
\hline $\begin{array}{l}\text { Happy damaging the } \\
\text { property of others }\end{array}$ & 7 & $7 \%$ & 7 & $7 \%$ & 20 & $21 \%$ & 63 & $65 \%$ \\
\hline $\begin{array}{l}\text { Holding friends with } \\
\text { lust }\end{array}$ & 5 & $5 \%$ & 3 & $3 \%$ & 12 & $12 \%$ & 79 & $81 \%$ \\
\hline $\begin{array}{l}\text { Eliminate other } \\
\text { people's money }\end{array}$ & 6 & $6 \%$ & 4 & $4 \%$ & 11 & $11 \%$ & 62 & $64 \%$ \\
\hline $\begin{array}{l}\text { Drop their trousers / } \\
\text { skirt }\end{array}$ & 3 & $3 \%$ & 3 & $3 \%$ & 8 & $8 \%$ & 81 & $84 \%$ \\
\hline $\begin{array}{l}\text { Threatened or forced } \\
\text { to act the bully }\end{array}$ & 4 & $4 \%$ & 4 & $4 \%$ & 6 & $6 \%$ & 83 & $86 \%$ \\
\hline
\end{tabular}

\section{Behaviour Typology Leads to Bullying Often Happen at School}

Based on the questionnaire above recapitulation, it is known that the mock friends who have physical limitations get 19\% followed the habit of ridicule, which is not based on the fact get $18 \%$, the answer of the questionnaire also proves that take their seniority among students, excluded from study groups, humiliated in public and trapped by friends gained $11 \%$. 
Getting kicked, using social networking media to embarrass friends found $10 \%$ of respondents.

\section{Appropriate Islamic Intervention Program for Perpetrator Bullying}

Based on interviews with counselling teachers and religious teacher about the appropriate approach to do stated that we always try to find information from various parties what actually happened and why the bully behaviour happen among students. Then the statement is reinforced by Nuben Karim who is senior religious teachers at SMAN 8 Pekanbaru said the same thing that if it finds bully behavior among students they quickly to find information causes and what happened.

Making the cozy atmosphere, safe school environment as a mandatory, are the result of researcher's interview with religious teachers of SMAN 7 and Eviaty Zay counselling teachers of SMAN 2 Pekanbaru, then, needs to be disseminated that the bully's behavior is disorderly conduct and it is prohibited by religion and State, as stated by Anendyawati and Nurhayati of counselling teachers. He added that it needs to be delivered to students because many students do not know about it.

Then, an effort carried out by school is to help children of bullying victims by doing a variety of ways to cope discomfort received by bully victim. In addition, teachers, parents and all parties need to cooperate with each other in school and always observe the behavior of the as well as victims of bullies. Students need to be equipped with the technical capability to deal with the situation particularly suspicious of actors bully, recognize suspicious behavior in various situations.

It needed to intensify guidance and counseling services and optimizing peer coaching in schools is a matter that should be maximized. To perform peer coaching, it requires a teacher who puts himself as a friend and always gives an opportunity to bully victims to tell what really happened without fear. Then it does the religious mentoring by tausyiah and wirid weekly, periodic muhasabah also as an activity or program that could be done school. Utilizing the existing IT media about bully behaviour and its danger can also be done school, so that these activities can reduce bullying.

Here are some formulas of Islamic intervention program model do by religious and counselling teachers in dealing with perpetrators of bullying among high school students as the city of Pekanbaru (FGD with teachers related) include:

a. Streamline group counseling, mediation counseling and information

Counseling services group is one of guidance and counseling services in schools. Group counselling services integrated implement guidance and 
counselling services in schools. As activity, group counselling service is an effort to help students solve problems by leveraging group dynamics.

Every school must create a planning program which is the basic reference for the implementation of guidance and counseling services unit. The plan contains the areas of service, type of service which is allocated according to time, the division of lab or organizers and facilities/infrastructure to support the activities of guidance and counseling services.

Various types of services and activities need to be done as a form of guidance service delivery to target services, namely learners. There are guidance and counselling services to students, namely service orientation, information, placement and distribution, learning, group counseling, individual counseling and group counseling.

Group counselling service is guidance and counselling services allow learners get opportunity for discussion and the alleviation of the problems experienced through group dynamics. Group dynamics is a lively, pulsating, moving, evolving, characterized by the interactions among group members. A group counseling services and counseling services are organized in a group atmosphere.

The process contains the characteristics of such therapeutic disclosure thoughts and feelings freely, orientation in fact, opening up the deep feelings experienced, mutual trust, mutual concern, mutual understanding, and mutual support. Group counselling objectives include:

1) Train members of the group to dare to speak to the crowd.

2) Train members of the group can be tolerant towards peers.

3) Develop talents and interests of each group member.

4) Alleviating the problems of the group.

In group counseling activities, there are several elements that are referred to group counseling activities. The elements of counselling groups:

1) Members of the group, is individual who have had problems in the range of adjustments that are tackled by group leader or other group members.

2) The leader of the group, is an expert who lead group counselling activities. Counseling group led by a professional counselor or psychologist with special training to work with the group.

3) The problem faced among counselling members are similar.

4) The method implemented in the counselling group focused on group process and feeling of the group.

5) The interaction among group members a very important and cannot be second. 
6) Group counselling activities are conducted based on the consciousness of each group member and also the group leader.

7) Emphasizing on feelings and needs of members.

8) The existence of group dynamics among group members in group counseling activities.

9) There is an element of assistance performed by the group leader.

The type of approach that can be used in implementing Group Counselling services:

1) Counselling/therapy in group: This type is the individual approach done in a group. During the process of counselling/therapy, the other members just become observers.

2) Counselling/therapy with group: It usually encountered in a group meeting or group-T. Activity in the group is determined by the members. Counselors only act as an expert participant.

3) Counselling/therapy regarding group: This type is more emphasis on the interaction among members. It focuses on here and now. This group type more emphasis on helping each other, providing support and showing a model of good behavior. Counselors as leaders act as outside observers, and as an expert participant.

Material group counselling services include:

1) Understand and develop of attitudes, habits, talents, interests, and distribution.

2) Understand and solve weaknesses, the introduction and development strengths.

3) Planning and self-realization.

4) Develop ability to communicate, receive/expression ideas, behavioural and social relationships, either at home, school, and community.

5) Develop good peer relationships at home, school, and community in accordance with the conditions, rules subject matter.

6) Develop the attitude and study habits, discipline of study and practice, as well as techniques mastery of subject matter.

7) Understanding the physical, social, and cultural orientation in relation to study in college.

8) Develop a tendency career of students' choice.

9) The orientation and career information, employment, and future prospects.

10) Information in accordance with the college career will be developed.

11) Consolidation in the decision in order to self-realization. 
b. Streamline the mediation services

Mediation services are counselling service performed by counsellor toward two or more parties who are circumstances that do not find a match. Based on these meanings, mediation services also means services or assistance to two or more parties who are in a state of hostility. The purpose of mediation services include:

1) General purpose: Mediation service aims to achieve a positive relationship and conducive condition between the clients and the warring parties or hostile. In other words, it occurs in order to achieve a positive and conducive relationship between students who are hostile.

2) Specific objectives: Mediation service aims to change negative on initial conditions (conflicting or hostile) to the new conditions (conducive and friendly) in the relationship between the two parties is problematic. Early condition changes tend to be negative to the more positive tone.

\begin{tabular}{|c|c|}
\hline Init & \\
\hline 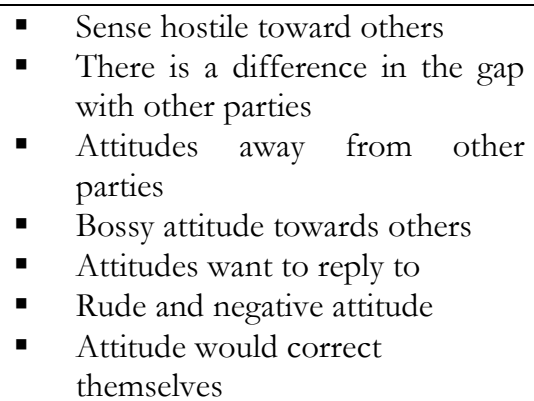 & $\begin{array}{l}\text { ul toward others } \\
\text { xistence of similarities with other } \\
\text { titude of approaching other parties } \\
\text { to give and take attitude towards } \\
\text { parties } \\
\text { titude of forgiveness } \\
\text { and positive attitude } \\
\text { les to understand }\end{array}$ \\
\hline
\end{tabular}

The achievement of the goal of mediation services above should not only up to the level of understanding and attitude (the function understanding) but actualized in real behaviour in a positive relationship that accompanies relations both parties relationship. The components related to the mediation service as follows:

1) The counsellor, is one understand the problems that occur between parties who have problems and are trying to build a bridge between the parties is problematic.

2) The client is two or more parties who are experiencing a mismatch and agreed to request a counsellor helping deal with that problem.

3) Clients' problems, is the problem of the relationship between individuals or groups in conflict and ask the counselor to overcome.

Some principles of mediation services

1) Confidentiality: The principle of secrecy must be adhered to in order the problems that were in the solution swatch was not even more 
widespread, or the solution becomes complicated. In the principle of the confidentiality of mediation services as it really emphasized by the counselor to be understood and practiced by all of participants service.

2) Disclosure: Mediation services followed by two men who followed the service should open up wide as possible in accordance with the issues discussed.

3) Voluntary: All participants must volunteer (self-referrals) to follow the mediation services. There is no compulsion component.

4) Present: Subject matter which becomes focus of discussion in mediation service is the things that are actual, which involves thoughts, feelings, perception, attitudes, and the slow lorises occur, are discussed in relation to current conditions.

5) Independence: With mediation services throughout the service participants is expected to develop their independence in thinking, feeling, opinion.

\section{Material / Content of Mediation Services}

Problems or contents that are discussed in mediation services are matters relating to the relationship between the individual -individuals (students) or the warring groups. These problems can include:

1) The dispute over the ownership of something

2) Genesis impromptu (fights) between students and group of students

3) Feeling offended

4) Revenge and hurt

5) Charges of rights etc.

Contents or issue and services discussed in mediation services is more regarding to the problems of individuals who relate to others or his environment (social issues). The problems become the content of the mediation service is not a matter of a criminal nature. In other words, individuals or groups who become clients in mediation services are not being involved in a criminal case are a matter for the police officer.

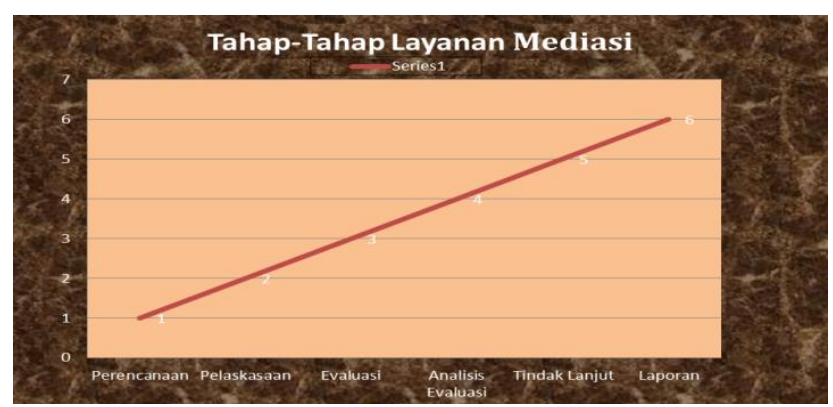


Implementation of mediation services also through the process or stages as follows:

Planning activities conducted at this stage are:

1) Identify the parties who will be the participants of service

2) Set up with candidates of service

3) Establish service facilities

4) Prepare administrative documents

Implementation which includes activities is as follows:

1) Accept the parties which is dispute or conflicting

2) Manage mediation services structure

3) Discussing the problems perceived by the parties who participated in the service

4) Organize changing behaviour of participants service

5) Fostering commitment to service participants for the sake of good relations with the other

6) Conduct assessment immediately (laiseg)

Evaluation

At this stage, the activities evaluate the results of mediation services. The focus of the evaluation from the results service gains new understanding of clients, developing positive feelings (comfort), and the activities done by the client (action) after the service takes place. Evaluation of the mediation service can be done in three stages, they are:

1) Evaluation or assessment of the immediate is focused on understanding (comprehension of new clients), comfort (the development of positive feelings), and action (activities will do by client after conducted service)

2) Evaluation or assessment of the short-term. The focus of this evaluation is the quality of the relationship between the two parties in dispute. The indicators are whether the problems that exist between them has really subsided, finished already, or whether it has been developed in harmony, mutual support and be positive and productive

3) Evaluation or assessment of the long-term. This assessment is deepening, expansion and stabilization of immediate assessment and short-term ratings in a long time span. Assessment in mediation service can be made orally, written, in individual or group format. A respondent for assessment of immediate is all participants, while for respondents to assess the short term and long term can be a vice of dispute or conflict.

Perform analysis of Evaluation Results

The activity in analysis of evaluation result is interpretation of evaluation result in relation to the problems' solving experienced by those who have followed mediation services. 
Conducting Follow-up, activity in this stage is conducting mediation services continuously to discuss the evaluation result and strengthening of peace efforts between dispute or conflict parties.

Reporting, the activities carried out this stage are:

1) Talking about reports need by the parties participants mediation services

2) Documenting reports

c. Making regular Mubasabah

Mubasabah in simple can be understood same as introspection, i.e. someone asks himself about the deeds that he did in order the soul becomes calm, and clearly ascertain whether the acts committed in his life according to the commandments of Allah Ta'ala. Because of mubasabah, our hearing becomes far from negligence, mouth avoids utter ugliness and our actions will be preserved from all vice and misguidance.

Thus, mubasabab means ideally that we need to do it every day. Mubasabah before committing, it is in order Muslim stops first for of desire and willing and do not hasten to do anything to unclear purpose. There are three questions at least that must be answered.

1) First, whether the act of willingness is able to do or not.

2) Second, whether the action was appropriate with syariat.

3) Third, whether the action was going to be done sincerely for Allah.

Meanwhile, for mubasabah after committing, can be checked through his actions whether syariat compliant and if done sincerely for Allah. According to Ibn Qayyim (1422, p. 134-135) mubasabah after performing actions can be divided on.

1) First, muhasabab on obedience ignored.

2) Second, mubasabab for any act which if it left better than done.

3) Third, mubasabah on permissible actions did not commit.

Furthermore Ibn Qudamah said, "it's better for every Muslim to set aside time in the morning and afternoon to mubasabah themselves. And he counted as traders and colleagues calculate profits and losses of their transactions each end of the sale.

\section{CONCLUSION}

Based on the data presentation at previous chapter it can be concluded that. Factors that influence the occurrence of bullying behavior among students of SMAN caused by external factors of students such the influence of parental education, lack of affection from parents, teachers' participation in elementary school, having peers who like to spoil and disturbing others. Besides the factor of self-esteem himself happy violate the norms and religious knowledge is very shallow. The typology of bullying behavior is 
often the case that the mock friends who have less of physical followed the habit of ridicule, which is not based on real evidence, the answer of the questionnaire also proves that there is seniority among students, excluded from study groups, humiliated in public and trapped by his own friends. Getting kicked, using social media to embarrass friends found $10 \%$ of respondents answer. There are forced to act by peers as well as the tendency to act a wanton lifted skirt, bra strap pull, spread personal photos without permission from a friend, grabbed bullying victim and other bullying behaviour. Model of intervention that can be done to streamline the peer coaching, religious mentoring periodically and intensive conducted by school with involving religious and counselling teachers maximize co-operation between parents, teachers and schools to make effective counselling group, mediation and use of ICT in the learning process.

It needs the cooperation of all parties, both from parents, teachers and school. Intensify peer coaching program collaborated between religious and counselling teachers. For schools, it needs to streamline the various educational programs relating to involve all components in the school. The case of bullying among students, both as perpetrators and victims of bullies should be thinking more in-depth and positive to work together is willing to stop the bullying activity because it is not profitable any party, even detrimental to all parties.

\section{BIBLIOGRAPHY}

Abd. Rahman Assegaf., (2004). Pendidikan Tanpa Kekerasan: Tipologi Kondisi, Kasus dan Konsep. Yogyakarta: Tiara Wacana Yogya.

Alamah Sayyid Muhammad Husain Thabathaba i., (1989). Inilab Islam: Upaya Memahami Seluruh Konsep Islam Secara Mudah. Jakarta: Pustaka Hidayah.

Amirah Diniaty., (2012). Keterampilan Empati dalam Penyelenggaraan Konseling Pasca Traumatik Untuk Korban Bullying di Sekolah Menengah. Prosiding International Seminar \& Workshop Post Traumatic Counseling

Barbara Coloroso., (2007). Stop Bullying. Jakarta: Serambi Ilmu Semesta.

Borg, WR and Gall, MD, (1989), Education Research, New York: Longman First Edition

Garna., (1991). Metode Penelitian Pendekatan Kualitatif. Bandung: PPs UNPAD. http://www.hezelden.com. Olweus Bullying Prevention Program. Accessed on 16 March 2013.

Ibnul Qayyim., (1422). Ighatsatul Lahfaan min Mashaayidhis Syaithan. Darul Kita Araby.

Kathryn Geldard. Konseling Remaja, Intervensi Praktis Bagi Remaja Berisiko. Yogyakarta: Pustaka Pelajar. 
Nissa Ardilla., (2009). Jurnal Kriminologi Indonesia: Pengarub Kontrol Sosial Terbadap Perilaku Bullying Pelajar di Sekolah Menengah Pertama. Jakarta: Kriminologi Fisip Universitas Indonesia. Olweus Bullying Prevention Program, hazelden. Com, Accessed on 16 March 2013

Novan Ardy Wiyani., (2012). Save Our Children from School Bullying. Jogjakarta: Ar-Ruzz Media.

Rina Mulyani., (2013). Pendekatan Konseling Spiritual Untuk Mengatasi Bullying (Kekerasan) Siswa di SMA Negeri 1 Depok Sleman Yuogyakarta. Yogyakarta: Jurusan Bimbingan Konseling Islam Fakultas Dakwah dan Komunikasi Universitas Sunan Kalijaga. Tidak diterbitkan. 